Original Research Paper

\title{
Geometry and Inverse Kinematic at the MP3R Mobile Systems
}

\author{
${ }^{1}$ Relly Victoria Virgil Petrescu, ${ }^{2}$ Raffaella Aversa, \\ ${ }^{2}$ Antonio Apicella, ${ }^{3}$ Samuel Kozaitis, \\ ${ }^{4}$ Taher Abu-Lebdeh and ${ }^{1}$ Florian Ion Tiberiu Petrescu \\ ${ }^{1}$ ARoTMM-IFToMM, Bucharest Polytechnic University, Bucharest, (CE) Romania \\ ${ }^{2}$ Advanced Material Lab, Department of Architecture and Industrial Design, \\ Second University of Naples, 81031 Aversa (CE) Italy \\ ${ }^{3}$ Florida Institute of Technology, USA \\ ${ }^{4}$ North Carolina A and T State University, USA
}

Article history

Received: 1-12-2017

Revised: 5-12-2017

Accepted: 12-12-2017

Corresponding Author: Florian Ion Tiberiu Petrescu ARoTMM-IFToMM,

Bucharest Polytechnic University, Bucharest, (CE), Romania

E-mail: scipub02@gmail.com

\begin{abstract}
The development and diversification of machines and mechanisms with applications in all fields require new scientific researches for the systematization and improvement of existing mechanical systems by creating new mechanisms adapted to modern requirements, which involve increasingly complex topological structures. The modern industry, the practice of designing and building machinery is increasingly based on the results of scientific and applied research. Each industrial achievement has backed theoretical and experimental computer-assisted research, which solves increasingly complex problems with advanced computing programs using an increasingly specialized software. The robotization of technological processes determines and influences the emergence of new industries, applications under special environmental conditions, the approach of new types of technological operations, manipulation of objects in the alien space, teleoperators in the top disciplines like medicine, robots covering a whole field greater service provision in our modern, computerized society. Movable, robotic, mechatronic mechanical systems have entered nearly all industrial spheres. Today, we can no longer conceive of industrial production without these extremely useful systems. They are still said to steal from people's jobs. Even so, it should be made clear that these systems create value, work in difficult, repetitive, non-pausing, high-quality work, without getting tired, without getting sick, without salary, and producing value who are paid and people left without jobs, so that they can work elsewhere in more pleasant, more advantageous conditions, with the necessary breaks. In other words, robots do not destroy people but help them in the process of work. Let us not remember the fact that in some environments people could not even work. In fact, the robot's profitability for work without stopping, repetitive, and qualitative, is no longer in question. In addition, there are many heavy operations that are absolutely necessary for the presence of robots. You can not create microchips with people directly without interposing the robot. Man can not directly work with objects of such small size. Neither difficult medical operations can be designed without robotic mechatronic systems. The most used robotic mechanical mechanical systems are the anthropomorphic ones in the class of serial systems. To this we have studied the direct kinematics in previous castings, and in this paper we are going to study the inverse kinematics.
\end{abstract}

Keywords: Mechanism, Robots, Mechatronics, Mechanical Systems 


\section{Introduction}

The development and diversification of machines and mechanisms with applications in all fields require new scientific researches for the systematization and improvement of existing mechanical systems by creating new mechanisms adapted to modern requirements, which involve increasingly complex topological structures.

The modern industry, the practice of designing and building machinery is increasingly based on the results of scientific and applied research. Each industrial achievement has backed theoretical and experimental computer-assisted research, which solves increasingly complex problems with advanced computing programs using an increasingly specialized software.

The robotization of technological processes determines and influences the emergence of new industries, applications under special environmental conditions, the approach of new types of technological operations, manipulation of objects in the alien space, teleoperators in the top disciplines like medicine, robots covering a whole field greater service provision in our modern, computerized society. Movable, robotic, mechatronic mechanical systems have entered nearly all industrial spheres.

Today, we can no longer conceive of industrial production without these extremely useful systems. They are still said to steal from people's jobs. Even so, it should be made clear that these systems create value, work in difficult, repetitive, non-pausing, high-quality work, without getting tired, without getting sick, without salary, and producing value who are paid and people left without jobs, so that they can work elsewhere in more pleasant, more advantageous conditions, with the necessary breaks. In other words, robots do not destroy people but help them in the process of work.

Let us not remember the fact that in some environments people could not even work. In fact, the robot's profitability for work without stopping, repetitive, and qualitative, is no longer in question. In addition, there are many heavy operations that are absolutely necessary for the presence of robots. You can't create microchips with people directly without interposing the robot. Man can not directly work with objects of such small size. Neither difficult medical operations can be designed without robotic mechatronic systems.

The most used robotic mechanical mechanical systems are the anthropomorphic ones in the class of serial systems. To this we have studied the direct kinematics in previous castings, and in this paper we are going to study the inverse kinematics.

As examples of such combined mechanisms, several kinematic schemes of gears and gears can be observed, presented by Kojevnikov (1969), Volmer (AUTORENKOLLEKTIV, 1968), Şaskin (1963; 1971), Maros (1958), Rehwald and Luck (2000-2001), Antonescu (993; 2003; Antonescu and Mitrache, 1989).

The main problems with plane and spatial gears and gears refer to kinematic analysis and geometrickinematic synthesis under certain conditions imposed by technological processes, Bruja and Dima (2011), Buda and Mateucă (1989), Luck and Modler (1995), Niemeyer (2000), Tutunaru (1969), Popescu (1977), Braune (2000), Dudita et al. (1989), Lichtenheldt (1995), Lederer (1993), Lin (1999), Modler and Wadewitz (1998; 2001; Modler, 1979), Neumann (1979; 2001), Stoica (1977), Petrescu and Petrescu (2011c-d; Petrescu, 2012d-e); (Petrescu, 2016; 2017a-q; Aversa et al., 2017ae; 2016a-o; Mirsayar et al., 2017; Petrescu and Petrescu, 2016a-c; 2013a-d; 2012a-d; 2011a-b; Petrescu, 2012a-c; 2009; Petrescu and Calautit, 2016a-b; Petrescu et al., 2016a-b; Maros, 1958; Modler and Wadewitz, 2001; Manolescu et al., 1968; Margine, 1999).

\section{Materials and Methods}

Inverse kinematic manipulators and serial robots will be exemplified for the 3R cinematic model (Fig. 1). In the inverse kinematics, we already know the direct relation relations (1) and we have to determine the inverse relations, ie to determine the independent rotation $\phi_{10}, \phi_{20}, \phi_{30}$ of the three movable elements, depending on the kinematic parameters imposed to the enforcer $x_{M}, y_{M}, z_{M}$, known (given, imposed). With the determined independent angles, then the relative rotations corresponding to the movements of the three drive motors in the rotation couplers (drives of the actuators) will be located:

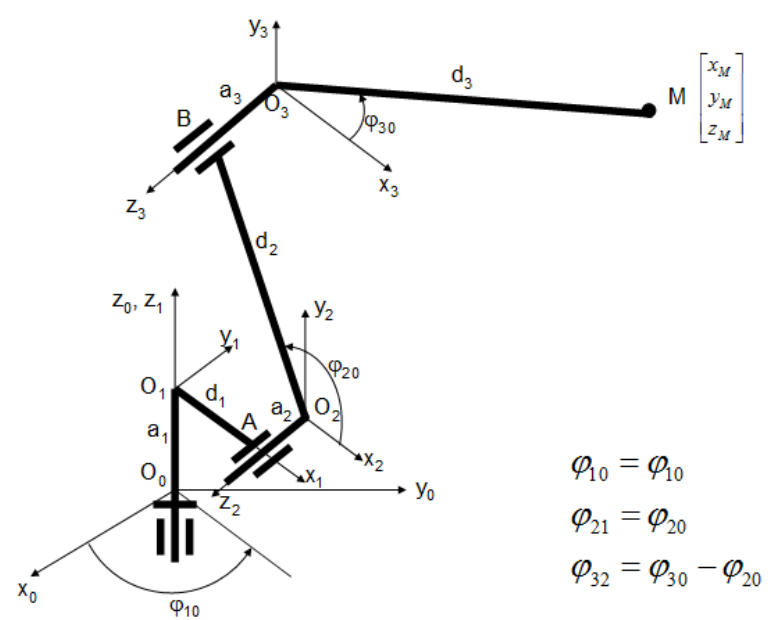

Fig. 1. The geometry and kinematics of a MP3R 


$$
\left\{\begin{array}{l}
x_{M}=d_{3} \cos \phi_{10} \cdot \cos \phi_{30}+d_{2} \cos \phi_{10} \cdot \cos \phi_{20}- \\
a_{3} \sin \phi_{10}+d_{1} \cos \phi_{10}-a_{2} \sin \phi_{10} \\
y_{M}=d_{3} \sin \phi_{10} \cdot \cos \phi_{30}+d_{2} \sin \phi_{10} \cdot \cos \phi_{20}+ \\
a_{3} \cos \phi_{10}+d_{1} \sin \phi_{10}+a_{2} \cos \phi_{10} \\
z_{M}=d_{3} \sin \phi_{30}+d_{2} \sin \phi_{20}+a_{1}
\end{array}\right.
$$

The fixed coordinate system was denoted by $x_{0} O_{0} y_{0} z_{0}$. The mobile systems (rigidized) of the three mobile elements $(1,2,3)$ have indices 1,2 and 3 . Their orientation has been chosen conveniently.

The system (1) is a transcedental system of three equations (1.1-1.3) with three unknowns $\left(\phi_{10}, \phi_{20}, \phi_{30}\right)$ to be determined; the equations of the system 1 are rearranged in the form that can be seen in the system (1'):

$$
\left\{\begin{array}{l}
x_{\mathrm{M}}=d_{1} \cdot \cos \phi_{10}-a_{2} \cdot \sin \phi_{10}+d_{2} \cdot \cos \phi_{20} \cdot \cos \phi_{10}- \\
a_{3} \cdot \sin \phi_{10}+d_{3} \cdot \cos \phi_{30} \cdot \cos \phi_{10}(1.1) \\
y_{M}=d_{1} \cdot \sin \phi_{10}+a_{2} \cdot \cos \phi_{10}+d_{2} \cdot \cos \phi_{20} \cdot \sin \phi_{10}+ \\
a_{3} \cdot \cos \phi_{10}+d_{3} \cdot \cos \phi_{30} \cdot \sin \phi_{10}(1.2) \\
z_{M}=a_{1}+d_{2} \cdot \sin \phi_{20}+d_{3} \cdot \sin \phi_{30}(1.3)
\end{array}\right.
$$

It is desirable to solve the system (1') directly by obtaining independent exact solutions.

The first step is the multiplication of the equation (1.1) with $-\sin \phi_{10}$ and of the relation (1.2) with $\cos \phi_{10}$, after which the two resulting expressions are obtained by obtaining the trigonometric equation (2) which is solved with the solutions (3), i.e. for the first independent parameter $\phi_{10}$ trigonometric functions of cosine and sinus functions:

$-x_{M} \cdot \sin \phi_{10}+y_{M} \cdot \cos \phi_{10}=a_{2}+a_{3}$

$$
\left\{\begin{array}{l}
\cos \phi_{10}=\frac{\left(a_{2}+a_{3}\right) \cdot y_{M} \pm x_{M} \cdot \sqrt{x_{M}^{2}+y_{M}^{2}-\left(a_{2}+a_{3}\right)^{2}}}{x_{M}^{2}+y_{M}^{2}} \\
\sin \phi_{10}=\frac{-\left(a_{2}+a_{3}\right) \cdot x_{M} \pm y_{M} \cdot \sqrt{x_{M}^{2}+y_{M}^{2}-\left(a_{2}+a_{3}\right)^{2}}}{x_{M}^{2}+y_{M}^{2}}
\end{array}\right.
$$

When we want to get the value of an angle directly when we know sin and cos functions, we use the expression (4):

$$
\phi_{10}=\operatorname{semn}\left(\sin \phi_{10}\right) \cdot \arccos \left(\cos \phi_{10}\right)
$$

The angle is given directly by the arctic function, and its sinus sign, which can be +1 or -1 , sends the angle in its quadrant, in the top or bottom half circle.
At the next step we multiply equation (1.1) with $\cos \phi_{10}$ and relation (1.2) with $\sin \phi_{10}$, we add the obtained expressions and obtain the trigonometric equation (5):

$$
x_{M} \cdot \cos \phi_{10}+y_{M} \cdot \sin \phi_{10}-d_{1}=d_{2} \cdot \cos \phi_{20}+d_{3} \cdot \cos \phi_{30}
$$

This together with relation (1.3) forms the system (6) generating the last independent parameters:

$$
\left\{\begin{array}{l}
x_{M} \cdot \cos \phi_{10}+y_{M} \cdot \sin \phi_{10}-d_{1}=d_{2} \cdot \cos \phi_{20}+d_{3} \cdot \cos \phi_{30}(5) \\
z_{M}-a_{1}=d_{2} \cdot \sin \phi_{20}+d_{3} \cdot \sin \phi_{30}(1.3)
\end{array}\right.
$$

With the notations (7) we obtain for the equation system (6) the direct and exact solutions (8); equations (6) take shape (6'):

$\left\{C_{1}=d_{2} \cdot \cos \phi_{20}+d_{3} \cdot \cos \phi_{30}\left(5^{\prime}\right)\right.$

$\left\{C_{2}=d_{2} \cdot \sin \phi_{20}+d_{3} \cdot \sin \phi_{30}\left(1.3^{\prime}\right)\right.$

The system $\left(6^{\prime}\right)$ is written in the form ( $6^{\prime}$ '):

$\left\{\begin{array}{l}C_{1}-d_{2} \cdot \cos \phi_{20}=d_{3} \cdot \cos \phi_{30} \\ C_{2}-d_{2} \cdot \sin \phi_{20}=d_{3} \cdot \sin \phi_{30}\end{array}\right.$

Equations (6") rise to squares each and then add, yielding (6"') expression:

$K-2 \cdot C_{1} \cdot d_{2} \cdot \cos \phi_{20}=2 \cdot C_{2} \cdot d_{2} \cdot \sin \phi_{20}$

The expression (6"') rises to the square and results in a second degree equation in $\cos ^{2} \phi_{20}$ which it generates the solutions for $\cos \phi_{20}$ and for the sin changes the form of the equation (6"') the terms with $\sin$ and $\cos$ permeating each other so that after lifting the square expression of the equation to be in $\sin ^{2} \phi_{20}$ and thus generating the solutions for the sin function.

With the two sin and cos phrases it is possible to calculate exactly the value of the angle, which will be given by the arctic, and will take over the upper semicircle for a positive sinus, and the inferior half circle for a negative sinus sign.

The algorithm can be resumed for the angle $\phi_{30}$ similarly, putting the system (6 ") corresponding (do the rocks $\cos \phi_{20}$ with $\cos \phi_{30}$ and $\sin \phi_{20}$ with $\left.\sin \phi_{30}\right)$; follows the algorithm described above by picking up the square, etc...

To make sure that all solutions satisfy the system simultaneously, trigonometric $\phi_{30}$ angle values are extracted directly from the system ( 6 "). Their expression depends directly on the value of the angle calculated at 
the previous step $\left(\phi_{20}\right)$, but all values surely satisfy the system from which they were deducted:

$$
\begin{aligned}
& \left\{\begin{array}{l}
C_{1}=x_{M} \cdot \cos \phi_{10}+y_{M} \cdot \sin \phi_{10}-d_{1} \\
C_{2}=z_{M}-a_{1} \\
k=C_{1}^{2}+C_{2}^{2}+d_{2}^{2}-d_{3}^{2}
\end{array}\right. \\
& \left\{\begin{array}{l}
\cos \phi_{20}= \\
=\frac{k \cdot C_{1} \pm C_{2} \cdot \sqrt{4 \cdot C_{1}^{2} \cdot d_{2}^{2}+4 \cdot C_{2}^{2} \cdot d_{2}^{2}-k^{2}}}{2 \cdot\left(C_{1}^{2}+C_{2}^{2}\right) \cdot d_{2}} \\
\sin \phi_{20}= \\
k \cdot C_{2} \mp C_{1} \cdot \sqrt{4 \cdot C_{1}^{2} \cdot d_{2}^{2}+4 \cdot C_{2}^{2} \cdot d_{2}^{2}-k^{2}} \\
2 \cdot\left(C_{1}^{2}+C_{2}^{2}\right) \cdot d_{2} \\
\phi_{20}=\operatorname{semn}\left(\sin \phi_{20}\right) \cdot \arccos \left(\cos \phi_{20}\right) \\
\cos \phi_{30}=\frac{C_{1}-d_{2} \cdot \cos \phi_{20}}{d_{3}} \\
\sin \phi_{30}=\frac{C_{2}-d_{2} \cdot \sin \phi_{20}}{d_{3}} \\
\phi_{30}=\operatorname{semn}\left(\sin \phi_{30}\right) \cdot \arccos \left(\cos \phi_{30}\right)
\end{array}\right.
\end{aligned}
$$

\section{Results}

\section{Determination of Actuator Angular Speeds}

We start from equation 2:

$$
-x_{M} \cdot \sin \phi_{10}+y_{M} \cdot \cos \phi_{10}=a_{2}+a_{3}
$$
(9):

We derive the equation (2) and obtain the relation

$$
\begin{aligned}
& -\dot{x}_{M} \cdot \sin \phi_{10}-x_{M} \cdot \cos \phi_{10} \cdot \omega_{10}+ \\
& +\dot{y}_{M} \cdot \cos \phi_{10}-y_{M} \cdot \sin \phi_{10} \cdot \omega_{10}=0
\end{aligned}
$$

Equation (9) is arranged in the form (10):

$$
\begin{aligned}
& \left(x_{M} \cdot \cos \phi_{10}+y_{M} \cdot \sin \phi_{10}\right) \cdot \omega_{10}= \\
& =\dot{y}_{M} \cdot \cos \phi_{10}-\dot{x}_{M} \cdot \sin \phi_{10}
\end{aligned}
$$

The angular velocity of the first actuator has the expression (11):

$$
\omega_{10}=\frac{\dot{y}_{M} \cdot \cos \phi_{10}-\dot{x}_{M} \cdot \sin \phi_{10}}{x_{M} \cdot \cos \phi_{10}+y_{M} \cdot \sin \phi_{10}}
$$

From the derived (6") system we obtain the angular speeds of the other two actuators. Draw (6") and result the system (12):

$$
\begin{aligned}
& \left\{\begin{array}{l}
C_{1}-d_{2} \cdot \cos \phi_{20}=d_{3} \cdot \cos \phi_{30}\left(5^{\prime \prime}\right) \\
C_{2}-d_{2} \cdot \sin \phi_{20}=d_{3} \cdot \sin \phi_{30}(1.3 ")
\end{array}\right. \\
& \left\{\begin{array}{l}
\dot{C}_{1}+d_{2} \cdot \sin \phi_{20} \cdot \omega_{20}=-d_{3} \cdot \sin \phi_{30} \cdot \omega_{30} \\
\dot{C}_{2}-d_{2} \cdot \cos \phi_{20} \cdot \omega_{20}=d_{3} \cdot \cos \phi_{30} \cdot \omega_{30}
\end{array}\right.
\end{aligned}
$$

We multiply the first relationship of the system (12) with $\cos \phi_{30}$ and the second one with $\sin \phi_{30}$, after which we collect the resulting relations and get the expression (13):

$\dot{C}_{1} \cdot \cos \phi_{30}+\dot{C}_{2} \cdot \sin \phi_{30}+d_{2} \cdot \sin \phi_{20} \cdot \cos \phi_{30} \cdot \omega_{20}-$
$-d_{2} \cdot \sin \phi_{30} \cdot \cos \phi_{20} \cdot \omega_{20}=$
$=-d_{3} \cdot \sin \phi_{30} \cdot \cos \phi_{30} \cdot \omega_{30}+d_{3} \cdot \sin \phi_{30} \cdot \cos \phi_{30} \cdot \omega_{30}$

The relationship (13) is written in the form (14):

$\dot{C}_{1} \cdot \cos \phi_{30}+\dot{C}_{2} \cdot \sin \phi_{30}+d_{2} \cdot \sin \phi_{20} \cdot \cos \phi_{30} \cdot \omega_{20}-$ $-d_{2} \cdot \sin \phi_{30} \cdot \cos \phi_{20} \cdot \omega_{20}=0$

The relationship (14) is in the form (15):

$\dot{C}_{1} \cdot \cos \phi_{30}+\dot{C}_{2} \cdot \sin \phi_{30}+d_{2} \cdot \sin \left(\phi_{20}-\phi_{30}\right) \cdot \omega_{20}=0$

From (15) we explain the angular velocity of the second actuator, and we get the relation (16):

$$
\omega_{20}=\frac{\dot{C}_{1} \cdot \cos \phi_{30}+\dot{C}_{2} \cdot \sin \phi_{30}}{d_{2} \cdot \sin \left(\phi_{30}-\phi_{20}\right)}
$$

Then we multiply the first relation of the system (12) with $\cos \phi_{20}$ and the second one with $\sin \phi_{20}$, after which we collect the resulting relations and get the expression (17):

$$
\begin{aligned}
& \dot{C}_{1} \cdot \cos \phi_{20}+\dot{C}_{2} \cdot \sin \phi_{20}+d_{2} \cdot \sin \phi_{20} \cdot \cos \phi_{20} \cdot \omega_{20}- \\
& -d_{2} \cdot \sin \phi_{20} \cdot \cos \phi_{20} \cdot \omega_{20}= \\
& =d_{3} \cdot \sin \phi_{20} \cdot \cos \phi_{30} \cdot \omega_{30}-d_{3} \cdot \sin \phi_{30} \cdot \cos \phi_{20} \cdot \omega_{30}
\end{aligned}
$$

The relationship (17) is written in the form (18):

$\dot{C}_{1} \cdot \cos \phi_{20}+\dot{C}_{2} \cdot \sin \phi_{20}=d_{3} \cdot \sin \left(\phi_{20}-\phi_{30}\right) \cdot \omega_{30}$

From (18) we explain the angular velocity of the last actuator, and we get the relation (19):

$\omega_{30}=\frac{\dot{C}_{1} \cdot \cos \phi_{20}+\dot{C}_{2} \cdot \sin \phi_{20}}{d_{3} \cdot \sin \left(\phi_{20}-\phi_{30}\right)}$

The angular speeds of the three actuators will be further explained in the system (20): 


$$
\left\{\begin{array}{l}
\omega_{10}=\frac{\dot{y}_{M} \cdot \cos \phi_{10}-\dot{x}_{M} \cdot \sin \phi_{10}}{x_{M} \cdot \cos \phi_{10}+y_{M} \cdot \sin \phi_{10}} \\
\omega_{20}=\frac{\dot{C}_{1} \cdot \cos \phi_{30}+\dot{C}_{2} \cdot \sin \phi_{30}}{d_{2} \cdot \sin \left(\phi_{30}-\phi_{20}\right)} \\
\omega_{30}=\frac{\dot{C}_{1} \cdot \cos \phi_{20}+\dot{C}_{2} \cdot \sin \phi_{20}}{d_{3} \cdot \sin \left(\phi_{20}-\phi_{30}\right)}
\end{array}\right.
$$

Several parameters must be calculated for their determination.

With relation (21) we note the variable parameter $\mathrm{C} 1$ :

$$
C_{1}=x_{M} \cdot \cos \phi_{10}+y_{M} \cdot \sin \phi_{10}-d_{1}
$$

We derive (21) and get $\dot{C}_{1}$ (relationship 22):

$\dot{C}_{1}=\dot{x}_{M} \cdot \cos \phi_{10}-x_{M} \cdot \sin \phi_{10} \cdot \omega_{10}+$

$+\dot{y}_{M} \cdot \sin \phi_{10}+y_{M} \cdot \cos \phi_{10} \cdot \omega_{10}$

Variable C2 is the simpler expression (23):

$C_{2}=z_{M}-a_{1}$

The relation (23) is derived and obtained for $\dot{C}_{2}$ expression (24):

$$
\dot{C}_{2}=\dot{z}_{M}
$$

\section{Discussion}

The development and diversification of machines and mechanisms with applications in all fields require new scientific researches for the systematization and improvement of existing mechanical systems by creating new mechanisms adapted to modern requirements, which involve increasingly complex topological structures.

The modern industry, the practice of designing and building machinery is increasingly based on the results of scientific and applied research.

Each industrial achievement has backed theoretical and experimental computer-assisted research, which solves increasingly complex problems with advanced computing programs using an increasingly specialized software.

The robotization of technological processes determines and influences the emergence of new industries, applications under special environmental conditions, the approach of new types of technological operations, manipulation of objects in the alien space, teleoperators in the top disciplines like medicine, robots covering a whole field greater service provision in our modern, computerized society. Movable, robotic, mechatronic mechanical systems have entered nearly all industrial spheres.
Today, we can no longer conceive of industrial production without these extremely useful systems. They are still said to steal from people's jobs. Even so, it should be made clear that these systems create value, work in difficult, repetitive, non-pausing, high-quality work, without getting tired, without getting sick, without salary, and producing value who are paid and people left without jobs, so that they can work elsewhere in more pleasant, more advantageous conditions, with the necessary breaks. In other words, robots do not destroy people but help them in the process of work.

Let us not remember the fact that in some environments people could not even work. In fact, the robot's profitability for work without stopping, repetitive, and qualitative, is no longer in question. In addition, there are many heavy operations that are absolutely necessary for the presence of robots. You can not create microchips with people directly without interposing the robot. Man can not directly work with objects of such small size. Neither difficult medical operations can be designed without robotic mechatronic systems.

The most used robotic mechanical mechanical systems are the anthropomorphic ones in the class of serial systems. To this we have studied the direct kinematics in previous castings, and in this paper we are going to study the inverse kinematics.

\section{Conclusion}

The inverse kinematics is the one that corresponds to the daily reality in which the robots are programmed to work in order to perform certain operations, to observe some imposed trajectories so that they move precisely to achieve and achieve the desired trajectory and all necessary kinematic parameters.

\section{Acknowledgment}

This text was acknowledged and appreciated by Dr. Veturia CHIROIU Honorific member of Technical Sciences Academy of Romania (ASTR) PhD supervisor in Mechanical Engineering and by Prof. BERTHOLD GRUNWALD, Past Director Mercedes Benz Daimler AG, Germany and Past Head Department of Automotive Engineering from Bucharest Polytechnic University, whom we thank and in this way.

\section{Funding Information}

Research contract: Contract number 27-7-7/1987, beneficiary Central Institute of Machine Construction from Romania (and Romanian National Center for Science and Technology).

All these matters are copyrighted. 
Copyrights: 394-qodGnhhtej from 17-02-2010 13:42:18; 396-qkzAdFoDBc from 17-02-2010 17:43:22; 951-cnBGhgsHGr from 26-01-2011 16:29:02; 1375tnzjHFAqGF from 02-09-2011 15:19:23.

\section{Author's Contributions}

All the authors contributed equally to prepare, develop and carry out this manuscript.

\section{Ethics}

This article is original. Authors declare that are not ethical issues that may arise after the publication of this manuscript.

\section{References}

Antonescu, P. and M. Mitrache, 1989. Contributions to the synthesis of the mechanisms used as windscreen wipers. SYROM'89, Bucharest, 4: 23-32.

Antonescu, P., 1993. Synthesis of manipulators. Lito UPB, Bucureşti.

Antonescu, P., 2003. Mecanisms. Ed. Printech, Bucureşti.

AUTORENKOLLEKTIV (J. VOLMER Coordonator), 1968. Getriebetechnik-VEB, Verlag technik, bb. 345-390, Berlin.

Aversa, R., D. Parcesepe, R.V. Petrescu, G. Chen and F.I.T. Petrescu et al., 2016b. Glassy amorphous metal injection molded induced morphological defects. Am. J. Applied Sci., 13: 1476-1482.

Aversa, R., D. Parcesepe, R.V.V. Petrescu, F. Berto and G. Chen et al., 2017d. Process ability of bulk metallic glasses. Am. J. Applied Sci., 14: 294-301.

Aversa, R., E.M. Buzea, R.V. Petrescu, A. Apicella and M. Neacsa et al., 2016e. Present a mechatronic system havingable to determine the concentration of carotenoids. Am. J. Eng. Applied Sci., 9: 1106-1111.

Aversa, R., F. Tamburrino, R.V. Petrescu, F.I.T. Petrescu and M. Artur et al., 2016 d. Biomechanically inspired shape memory effect machines driven by muscle like acting NiTi alloys. Am. J. Applied Sci., 13: 1264-1271.

Aversa, R., F.I.T. Petrescu, R.V. Petrescu and A. Apicella, 2016a. Biomimetic FEA bone modeling for customized hybrid biological prostheses development. Am. J. Applied Sci., 13: 1060-1067. DOI: 10.3844/ajassp.2016.1060.1067

Aversa, R., F.I.T. Petrescu, R.V. Petrescu and A. Apicella, 2016o. Flexible stem trabecular prostheses. Am. J. Eng. Applied Sci., 9: 1213-1221.

Aversa, R., R.V. Petrescu, A. Apicella and F.I.T. Petrescu, 2016i. Mitochondria are naturally micro robots-a review. Am. J. Eng. Applied Sci., 9: 991-1002.
Aversa, R., R.V. Petrescu, A. Apicella and F.I.T. Petrescu, 2016j. We are addicted to vitamins $\mathrm{C}$ and E-A review. Am. J. Eng. Applied Sci., 9: 1003-1018.

Aversa, R., R.V. Petrescu, A. Apicella and F.I.T. Petrescu, 2016k. Physiologic human fluids and swelling behavior of hydrophilic biocompatible hybrid ceramo-polymeric materials. Am. J. Eng. Applied Sci., 9: 962-972.

Aversa, R., R.V. Petrescu, A. Apicella and F.I.T. Petrescu, 20161. One can slow down the aging through antioxidants. Am. J. Eng. Applied Sci., 9: 1112-1126.

Aversa, R., R.V. Petrescu, A. Apicella and F.I.T. Petrescu, 2016m. About homeopathy or «Similia similibus curentur 》. Am. J. Eng. Applied Sci., 9: 1164-1172.

Aversa, R., R.V. Petrescu, A. Apicella and F.I.T. Petrescu, 2016n. The basic elements of life's. Am. J. Eng. Applied Sci., 9: 1189-1197.

Aversa, R., R.V. Petrescu, A. Apicella, I.T.F. Petrescu and J.K. Calautit et al., 2017c. Something about the $\mathrm{V}$ engines design. Am. J. Applied Sci., 14: 34-52.

Aversa, R., R.V. Petrescu, B. Akash, R.B. Bucinell and J.M. Corchado et al., 2017b. Kinematics and forces to a new model forging manipulator. Am. J. Applied Sci., 14: 60-80.

Aversa, R., R.V. Petrescu, F.I.T. Petrescu and A. Apicella, 2016c. Smart-factory: Optimization and process control of composite centrifuged pipes. Am. J. Applied Sci., 13: 1330-1341.

Aversa, R., R.V. Petrescu, F.I.T. Petrescu and A. Apicella, 2016h. Biomimetic and evolutionary design driven innovation in sustainable products development, Am. J. Eng. Applied Sci., 9: 1027-1036.

Aversa, R., R.V. Petrescu, R. Sorrentino, F.I.T. Petrescu and A. Apicella, 2016f. Hybrid ceramo-polymeric nanocomposite for biomimetic scaffolds design and preparation. Am. J. Eng. Applied Sci., 9: 1096-1105.

Aversa, R., R.V.V. Petrescu, A. Apicella and F.I.T. Petrescu, 2017a. Nano-diamond hybrid materials for structural biomedical application. Am. J. Biochem. Biotechnol.

Aversa, R., R.V.V. Petrescu, B. Akash, R.B. Bucinell and J.M. Corchado et al., 2017e. Something about the balancing of thermal motors. Am. J. Eng. Applied Sci., 10: 200.217.

DOI: 10.3844/ajeassp.2017.200.217

Aversa, R., V. Perrotta, R.V. Petrescu, C. Misiano and F.I.T. Petrescu et al., 2016g. From structural colors to super-hydrophobicity and achromatic transparent protective coatings: Ion plating plasma assisted $\mathrm{TiO} 2$ and $\mathrm{SiO} 2$ Nano-film deposition. Am. J. Eng. Applied Sci., 9: 1037-1045.

Braune, R., 2000. Bewegungsdesign - Eine Kernkompetenz des Getriebe Technikers. VDI Berichte Nr. 1567, Dusseldorf: VDI - Verlag, S. 1-23. 
Bruja, A. and M. Dima, 2001. Synthesis of kinematics of harmonics reducers with rigid front element. Sixth Simp. Nat. Construction Machinery, 1: 53-59.

Buda, L. and C. Mateucă, 1989. Functional, cinematic and cinetostatic analysis of the lifting mechanism of the passenger carriages. SYROM'89, Bucharest, 4: 59-66.

Dudita, FL., et al., Articulated, inventive, cinematic mechanisms. Technical Publishing House, Bucharest.

Kojevnikov, S.N., 1969. Teoria mehanizmov i maşin. Izd. Maşinostroenie, Moskva.

Lederer, P., 1993. Dynamische synthese der ubertragungs-funktion eines Kurvengetriebes. Mech. Mach. Theory, 28: 23-29.

Lichtenheldt, W., 1995 Konstruktionslehre der Getriebe. Akademie - Verlag Berlin.

Lin, S., 1999. Getriebesynthese nach unscharfen Lagenvorgaben durch Positionierung eines vorbestimmten Getriebes. In: Fortschritt - Berichte VDI, Reihe 1. Nr. 313, Dusseldorf: VDI - Verlage.

Luck, K. and K.H. Modler, 1995. Getriebetechnik Analyse, Synthese, Optimierung. 2. Aufl. Berlin/ Heidelberg/ New York: Springer.

Manolescu, N.I. et al., 1968 Problems of machine theory and machines. Vol. II, E.D.P., Bucharest, 1968.

Margine, A.L., 1999 Contributions to the geometrickinematical and dynamic synthesis of planetary gears with cylindrical gears. PhD Thesis, U.P.B.

Maros, D., 1958. Gear wheel kinematic. Technical Publishing House, Bucharest.

Mirsayar, M.M., V.A. Joneidi, R.V.V. Petrescu, F.I.T. Petrescu and F. Berto, 2017. Extended MTSN criterion for fracture analysis of soda lime glass. Eng. Fracture Mechanics, 178: 50-59.

DOI: $10.1016 /$ j.engfracmech.2017.04.018

Modler, K.H. and C. Wadewitz, 1998. Trepte, U., Rechnergestutzte Synthese von Raderkoppelgetrieben als Vorschaltgetriebe zur Erzeugung nichtlinearer Antriebsbewegungen. Bericht zum DFG - Vorhaben Mo 537/5 - 1. TU Dresden.

Modler, K.H. and C. Wadewitz, 2001. Synthese von Raderkoppelgetriebe als Vorschaltgetriebe mit definierter Ungleichformigkeit. Wissenschaftliche Zeitschrift, TU-Dresden Nr., 3: 101-106.

Modler, K.H., 1979. Reakisierung von pilgerschritten durch zweiraderkoppel-getriebe. Dynamik und Getribetechnik, Vol. A, Dresda, VIII/1-VI/12.

Neumann, R., 1979. Einstellbare Raderkoppelgetriebe. Dynamik und Getribe-technik, A, Dresda.

Neumann, R., 2001. Dreiraderkoppel - schrittgetriebe mit zahnradern oder zahnriemen. Bucureşti, 3: 321-324.
Niemeyer, J., 2000. Das IGM - Getriebelexikon Wissensverarbeitung in der Getriebetechnik mit Hilfe der Internet - Technologie. In: IMG Kolloquium Getriebetechnik, Dittrich, G. (Hrsg.) Forschung \& Lehre 1972-2000. Aachen: Mainz, pp: 53-66.

Petrescu, F.I. and J.K. Calautit, 2016b. About the light dimensions. Am. J. Applied Sci., 13:321-325. DOI: 10.3844/ajassp.2016.321.325

Petrescu, F.I. and R.V. Petrescu, 2011a. Memories about Flight. 1st Edn., CreateSpace, pp: 652.

Petrescu, F.I. and R.V. Petrescu, 2011b. Mechanical Systems, Serial and Parallel - Course (in romanian), LULU Publisher, London, UK, 124 pages, ISBN 978-1-4466-0039-9, Romanian edition.

Petrescu, F.I. and R.V. Petrescu, 2011d. Dynamics of distribution mechanisms, Create Space publisher, USA, ISBN 978-1-4680-5265-7, pp: 188.

Petrescu, F.I. and R.V. Petrescu, 2012b. New Aircraft II. 1st Edn., Books on Demand, pp: 138.

Petrescu, F.I. and R.V. Petrescu, 2012c Mecatronicasisteme seriale si paralele. Create Space publisher, USA, ISBN 978-1-4750-6613-5, pp: 128.

Petrescu, F.I. and R.V. Petrescu, 2012d. Kinematics of the planar quadrilateral mechanism. Engevista, 14: 345-348.

Petrescu, F.I. and R.V. Petrescu, 2013d. Cinematics of the 3R Dyad, Engevista, 15: 118-124.

Petrescu, F.I. and R.V. Petrescu, 2016a Parallel moving mechanical systems kinematics. ENGE-VISTA, 18: 455-491.

Petrescu, F.I. and R.V. Petrescu, 2016b Direct and inverse kinematics to the anthropomorphic robots. ENGEVISTA, 18: 109-124.

Petrescu, F.I. and R.V. Petrescu, 2016c. Dynamic cinematic to a structure 2R. Revista Geintec-Gestao Inovacao E Tecnologias, 6: 3143-3154.

Petrescu, F.I., 2012d. Basis of Analysis and Optimization of Rigid Memory Systems - Course and Applications, Create Space publisher, USA, ISBN 978-1-4700-2436-9, pp: 164.

Petrescu, F.I., 2012e Theory of Mechanisms - Course and Applications (second edition), Create Space publisher, USA, ISBN 978-1-4792-9362-9, pp: 284.

Petrescu, F.I.T. and J.K. Calautit, 2016a. About Nano fusion and dynamic fusion, Am. J. Applied Sci., 13: 261-266.

Petrescu, F.I.T. and R.V. Petrescu, 2011c Planetary Trains (Romanian Edition), CreateSpace, USA, ISBN-13: 978-1468030419, pp: 204.

Petrescu, F.I.T., 2009. New aircraft. Proceedings of the 3rd International Conference on Computational Mechanics, Oct. 29-30, Brasov, Romania.

Petrescu, F.I.T., 2012a. Cold Nuclear Fusion, USA, Create Space, ISBN/EAN13: 1478234261/9781478234265, pp: 80. 
Petrescu, F.I.T., 2012b. Particle Annihilation-A source of renewable energy?

Petrescu, F.I.T., 2012c. Particle annihilation-a source of renewable energy? Infinite Energy.

Petrescu, F.I.T., 2016. Valorisation of RomanianRomanian Engineering Tradition: Create Space Publisher, USA, ISBN-13 9781537177984.

Petrescu, F.I.T., A. Apicella, R.V.V. Petrescu, S.P. Kozaitis and R.B. Bucinell et al., $2016 \mathrm{~b}$. Environmental protection through nuclear energy. Am. J. Applied Sci., 13:941-946.

Petrescu, F.I.T., A. Apicella, R.V.V. Petrescu, S.P. Kozaitis and R.B. Bucinell et al., $2016 \mathrm{~b}$. Environmental protection through nuclear energy. Am. J. Applied Sci., 13: 941-946.

Petrescu, R.V. and F.I. Petrescu, 2013a. Lockheed Martin. 1st Edn., CreateSpace, pp: 114.

Petrescu, R.V. and F.I. Petrescu, 2013b. Northrop. 1st Edn., CreateSpace, pp: 96.

Petrescu, R.V. and F.I. Petrescu, 2013c. The Aviation History or New Aircraft I Color. 1st Edn., CreateSpace, pp: 292.

Petrescu, R.V. and F.I.T. Petrescu, 2012a. Northrop. Books on Demand, ISBN-13: 978-3848209323, pp: 142.

Petrescu, R.V., R. Aversa, B. Akash, F. Berto and A. Apicella et al., 2017n. The modern flight. J. Aircraft Spacecraft Technol.

Petrescu, R.V., R. Aversa, B. Akash, F. Berto and A. Apicella et al., 2017o. Sustainable energy for aerospace vessels. J. Aircraft Spacecraft Technol.

Petrescu, R.V., R. Aversa, B. Akash, F. Berto and A. Apicella et al., 2017p. Unmanned helicopters. J. Aircraft Spacecraft Technol.

Petrescu, R.V., R. Aversa, B. Akash, F. Berto and A. Apicella et al., 2017q. Project HARP. J. Aircraft Spacecraft Technology.

Petrescu, R.V., R. Aversa, B. Akash, J. Corchado and F. Berto et al., 2017e. Our universe. J. Aircraft Spacecraft Technology, 1: 69-79.

Petrescu, R.V., R. Aversa, B. Akash, J. Corchado and F. Berto et al., 2017f. What is a UFO? J. Aircraft Spacecraft Technol., 1: 80-90.

Petrescu, R.V., R. Aversa, B. Akash, J. Corchado and F. Berto et al., 2017g About Bell Helicopter FCX-001 concept aircraft-a short review. J. Aircraft Spacecraft Technol., 1: 91-96.

Petrescu, R.V., R. Aversa, B. Akash, J. Corchado and F. Berto et al., 2017h Home at Airbus. J. Aircraft Spacecraft Technol., 1: 97-118.

Petrescu, R.V., R. Aversa, B. Akash, J. Corchado and F. Berto et al., 2017i. Airlander. J. Aircraft Spacecraft Technol., 1: 119-148.
Petrescu, R.V., R. Aversa, B. Akash, J. Corchado and F. Berto et al., 2017j. When Boeing is Dreaming-a review. J. Aircraft Spacecraft Technol., 1: 149-161.

Petrescu, R.V., R. Aversa, B. Akash, J. Corchado and F. Berto et al., 2017k. About Northrop Grumman. J. Aircraft Spacecraft Technol., 1: 162-185.

Petrescu, R.V., R. Aversa, B. Akash, J. Corchado and F. Berto et al., 20171. Some special aircraft. J. Aircraft Spacecraft Technol., 1: 186-203.

Petrescu, R.V., R. Aversa, B. Akash, J. Corchado and F. Berto et al., 2017m. About helicopters. J. Aircraft Spacecraft Technol., 1: 204-223.

Petrescu, R.V., R. Aversa, B. Akash, R. Bucinell and J. Corchado et al., 2017b. Modern propulsions for aerospace-Part II. J. Aircraft Spacecraft Technology, 1: 9-17.

Petrescu, R.V., R. Aversa, B. Akash, R. Bucinell and J. Corchado et al., 2017c. History of aviation-a short review. J. Aircraft Spacecraft Technology, 1: 30-49.

Petrescu, R.V., R. Aversa, B. Akash, R. Bucinell and J. Corchado et al., 2017d. Lockheed martin-a short review. J. Aircraft Spacecraft Technology, 1: 50-68.

Petrescu, R.V.V., R. Aversa, A. Apicella, F. Berto and S. Li et al., 2016a Ecosphere protection through green energy. Am. J. Applied Sci., 13: 1027-1032.

Petrescu, RV., R. Aversa, B. Akash, R. Bucinell and J. Corchado et al., 2017a. Modern Propulsions for Aerospace-A Review. J. Aircraft Spacecraft Technology, 1: 1-8.

Popescu, I., 1977. Design of planar mechanisms. Scrisul Românesc Publishing House of Craiova.

Rehwald, W. and K. Luck, 2000. Kosim Koppelgetriebesimulation. In: Fortschritt Berichte VDI, Reihe 1, Nr. 332. Dusseldorf: VDI Verlag.

Rehwald, W. and K. Luck, 2001. Betrachtungen zur Zahl der Koppelgetribetypen. Wissenschaftliche Zeitschrift der TU Dresda, 50: 107-115.

Şaskin, A.G., 1963. Sintezu zubciato-rîciajnîh mehanizmov $\mathrm{s}$ vâstoem. Teoria maşin I mehanizmov, Moskva, 94-95: 88-110.

Şaskin, A.G., 1971. Zubciato rîciajnîe mehanizmî. Izd. Maşinostroenie, Moskva.

Stoica, I.A., 1977. Gear wheel interference. DACIA Publishing House, Cluj-Napoca.

Tutunaru, D., 1969. Rectangular and inverse planar mechanisms. Technical Publishing House, Bucharest.

\section{Source of Figures:}

Petrescu and Petrescu, 2011b 